\title{
Carbohydrate-to-lipid ratio in extruded diets for Nile tilapia farmed in net cages
}

\author{
Juliano José de Oliveira Coutinhoo, ${ }^{\mathrm{a}, *}$, Ligia Maria Neira ${ }^{\mathrm{b}}$, Lidiane Cristina Gonçalves de Sandre ${ }^{\mathrm{b}}$, \\ Jesaias Ismael da Costa ${ }^{a}$, Maria Inez Espagnoli Geraldo Martins ${ }^{\mathrm{b}}$, Maria Célia Portella ${ }^{\mathrm{a}}$, \\ Dalton José Carneiro ${ }^{\mathrm{a}}$ \\ a Centro de Aquicultura da UNESP, Via de Acesso Professor Paulo Donato Castellane, S/N, 14884-900 Jaboticabal, São Paulo, Brazil \\ ' Universidade Estadual Paulista “Júlio de Mesquita Filho", Faculdade de Ciências Agrárias e Veterinárias Campus Jaboticabal, Via de Acesso Professor Paulo Donato \\ Castellane, S/N, 14884-900 Jaboticabal, São Paulo, Brazil
}

\section{A R T I C L E I N F O}

\section{Keywords:}

Economic cost

Fat

Oreochromis niloticus

Starch

\begin{abstract}
A B S T R A C T
The study evaluated productive and economic performance, physiological parameters and nutritional efficiency in net cage-reared Nile tilapia fed extruded diets containing four carbohydrate (CHO) and lipid (LIP) ratios. The 1280 fish in the trial were sex-reversed male Nile tilapia from the Gift strain $(157.54 \pm 3.50 \mathrm{~g})$. Fish were randomly distributed into 16 net cages $\left(1.0 \mathrm{~m}^{3}\right)$, with 80 tilapias per cage. The four practical diets were formulated with the same ingredients at different proportions of starch and soybean oil contained similar digestible protein (251.40 $\mathrm{g} \mathrm{Kg}^{-1}$ ), digestible energy (17.39 $\mathrm{Mj} \mathrm{Kg}^{-1}$ ) and CHO:LIP ratios of: 3.89, 4.87, 6.14 and 7.83 $\left(\mathrm{CHO}_{35} / \mathrm{LIP}_{9}, \mathrm{CHO}_{39} / \mathrm{LIP}_{8}, \mathrm{CHO}_{43} / \mathrm{LIP}_{7}\right.$ and $\mathrm{CHO}_{47} / \mathrm{LIP}_{6}$, respectively). The diets were provided four times a day, for 120 days. Fish fed a $\mathrm{CHO}_{43} / \mathrm{LIP}_{7}$ diet exhibited the best productive performance, with $252.01 \%$ percent weight gain (WG), $1.07 \pm 0.028 \%$ daily specific growth rate (SGR) and $462.08 \pm 5.06 \mathrm{~g}$ feed intake (FI). Fish fed the $\mathrm{CHO}_{43} / \mathrm{LIP}_{7}$ diet also showed the highest gross energy retention efficiency $(57.17 \pm 4.16 \%)$ and LIP use for weight gain $(13.71 \pm 1.47 \%) . \mathrm{CHO}_{39} / \mathrm{LIP}_{8}$ and $\mathrm{CHO}_{43} / \mathrm{LIP}_{7}$ diets produced the best economic performance, with partial net income of US\$ 75.27 and US\$ 73.40, respectively.
\end{abstract}

\section{Introduction}

With worldwide aquaculture expansion, gradual changes have been made in fish farming systems. A strong intensification has increased based on improving technologies production. Nile tilapia is one of the most produced species in the world, with about four million tonnes produced in 2015 (FAO, 2017). The production of fish in 2016 in Brazil was 507.12 thousand tonnes, and tilapia production was 239.09 thousand tonnes, representing $47.0 \%$ of the total fish production in the country (IBGE, 2016).

The Nile tilapia is distinguishable from other fish species by its fast growth under intensive farming and higher survive rate (Veras, 2013). Because of its excellent acclimatization capacity, the Nile tilapia can be produced under different farming systems, exhibiting good productive performance under different environmental conditions. Farmers seek to produce low-fat fish with high fillet yields, the qualities required to meet consumer demands (Hisano and Portz, 2007).

Carbohydrates are included in fish feed because they are less costly energy sources, even though carbohydrates are not classified as essential growth products for fish (Kamalam et al., 2017; Hemre and Deng, 2015) and fish utilize carbohydrates less efficiently, likely reflecting the natural diets in their respective habitats and hence enzymatic activity (Wilson 1994). Lipids perform essential and dynamic role in growth and health, neural and visual development, reproduction and quality of the fillet (Lim and Webster, 2001). The excess of lipids or carbohydrates in the diet impair lipid homeostasis and lead to excessive accumulation of lipids in the liver of farmed fish, followed by slow growth, low survival rate and low resistance to pathogens (Li et al., 2016).

The relative utilization of dietary carbohydrate varies between different fish species and is still not completely understood (Leenhouwers et al. 2007). It has been shown that tilapia juveniles can utilize $46 \%$ corn starch in foods containing $29 \%$ protein and an energy/protein ratio of $37.9 \mathrm{~kJ} \mathrm{~g}^{-1}$ without growth retardation, although the feed containing $22 \%$ starch was ideal (Wang et al., 2005). The optimal level of $10 \%$ lipid in diet was adequate for growth of hybrid tilapia reared in fresh water according to previous studies (El-Sayed and Garling, 1998;

\footnotetext{
* Corresponding author.

E-mail address: julianojcoutinho@gmail.com (J.J.d.O. Coutinho).
} 


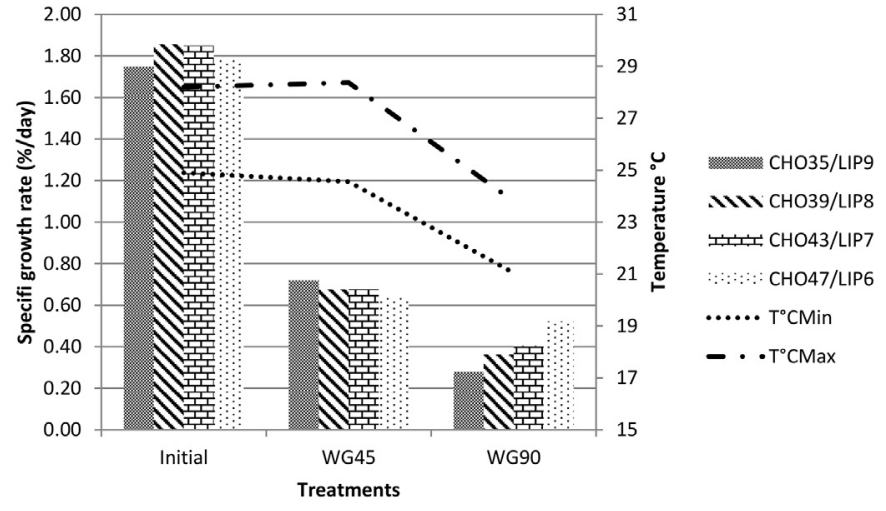

Fig. 1. Relationship between specific growth rate and water temperature of GIFT tilapia fed four experimental diets for 120 days. Data refer to fish reared in net cages housed within a $2000 \mathrm{~m}^{2}$ outdoor reservoir.

Chou and Shiau, 1996). Although lipids and carbohydrates are available for fish, lipid metabolism is reported to be highly modulated by dietary carbohydrates (He et al., 2015; Moro et al., 2015; Zhou et al., 2015; Tran-Duy et al., 2008).

There is no information about the exact carbohydrate-to-lipid (CHO: Lip) ratio of Nile tilapia reared in net cages until now. The present study evaluated practical diets for Nile tilapia with different CHO:LIP ratios in order to determine those that best meet the energy demands of fish farmed in net cages. Diet efficiency was based on productive and economic performance, nutrient use efficiency and physiological parameters of the fish.

\section{Material and methods}

\subsection{Experimental diets and design}

The study was performed for 120 days, in a reservoir measuring approximately $2000 \mathrm{~m}^{2}$ with a depth of $2 \mathrm{~m}$ from fall to early winter. In winter the temperature was acceptable but approaching the lower tolerable range for Nile (Fig. 1). Fish were held in 16 net cages with a usable volume of $1 \mathrm{~m} 3(1.0 \times 1.0 \times 1.2 \mathrm{~m})$ provided with feeder, arranged in two parallel lines positioned longitudinally to the pond, with eight cages per line. A paddle wheel aerator introduced between the cages was activated from 7:30 p.m. to 6:00 a.m. Temperature and dissolved oxygen were measured daily, in the morning and the afternoon, at a depth of $50 \mathrm{~cm}$, while water $\mathrm{pH}$, and electrical conductivity were measured weekly, in the morning ( 8 a.m.) and the afternoon (6 p.m.). Water samples were collected every 15 days for ammonia, nitrate, and nitrite determination (Koroleff, 1976; Golterman et al., 1978; Mackereth et al., 1978). The average values observed for the chemical parameters of the water, morning and afternoon, were: dissolved oxygen $5.27 \pm 1.36 \mathrm{mg} \mathrm{L}^{-1}$ and $4.05 \pm 0.23 \mathrm{mg} \mathrm{L}^{-1}, \mathrm{pH} 7.45 \pm$ 0.38 and $7.03 \pm 0.32$ and conductivity $63.06 \pm 1.48 \mu \mathrm{Sm} / \mathrm{cm}$ and $64.42 \pm 1.55 \mu \mathrm{Sm} / \mathrm{cm}$, respectively. The highest mean of dissolved oxygen in the morning in the pond were due to the presence of paddle wheel aerator, which were turned on from 7:30 p.m. to 6:00 a.m. The ammonia concentration of the pond was of $9.51 \pm 5.58 \mathrm{mg} \mathrm{L}^{-1}$. The levels of nitrate and nitrite were $56.12 \pm 17.86 \mathrm{mg} \mathrm{L}^{-1}$ and $1.57 \pm 0.54 \mathrm{mg} \mathrm{L}^{-1}$, respectively.

The test was carried out using 1280 sex-reversed male Nile tilapia juveniles from the Gift strain, with initial weight of $157.5 \pm 3.5 \mathrm{~g}$. Fish were kept at a density of $80 \mathrm{fish} / \mathrm{m}^{-3}$.

Fish were fed to satiety four times a day, at 8:30 a.m., 11:30 a.m., 2:30 p.m. and 5:30 p.m. Daily feed intake was calculated as the difference between feed offered and feed uneaten, the diet portions provided to each cage having been previously weighed.

Ingredient nutrients and energy were determined at the Laboratory of Aquatic Organism Nutrition of the São Paulo State University (Unesp), Aquaculture Center of Unesp, and at the Laboratory of Animal Nutrition of the School of Agricultural and Veterinarian Sciences, Jaboticabal, São Paulo.

Four experimental diets were formulated with different proportions of the same ingredients in order to contain similar values of digestible protein $\left(250 \mathrm{~g} \mathrm{Kg}^{-1}\right)$ and approximately $14.64 \mathrm{Mj} \mathrm{kg}^{-1}$ of digestible energy. The diets were produced with four CHO:LIP ratios: $3.89,4.87$, 6.14 and $7.83\left(\mathrm{CHO}_{35} / \mathrm{LIP}_{9}, \mathrm{CHO}_{39} / \mathrm{LIP}_{8}, \mathrm{CHO}_{43} / \mathrm{LIP}_{7}\right.$ and $\mathrm{CHO}_{47} / \mathrm{LIP}_{6}$, respectively) shown in Table 1 . The experimental design was completely randomized with four dietary treatments, and four replicates each.

The digestible nutrient and energy levels of diet were estimated from the chemical analyses and digestibility coefficients of the ingredients, protein and energy digestible as described by Pezzato et al. (2002) for Nile tilapia juveniles.

Diet ingredients were finely ground and sieved in $0.9 \mathrm{~mm}$ mesh and 6-8 $\mathrm{mm}$ feed pellets were processed at the Feed Manufacturing Facility of the Agricultural Sciences and Veterinary Medicine School of UNESP, Jaboticabal, São Paulo.

\subsection{Sampling and analysis}

The fish from each cage were weighted at the beginning and end of the experiment. Fish productive performance of each cage was evaluated by the survival rate, mean weight gain (WG), feed conversion ratio (FCR), protein efficiency ratio (PER) and specific growth rate (SGR), according to the following equations:

WG, $\%=\left[\frac{(\text { final weight }- \text { initial weight })}{\text { initial weight }}\right] \times 100$

$\mathrm{FCR}=\frac{\text { mean feed intake }}{\text { mean weight gain }}$

$\mathrm{PER}=\frac{\text { mean weight gain }}{\text { mean crude protein intake }}$

$\mathrm{SGR}=\frac{\ln \text { final mean weight }-\ln \text { initial mean weight }}{\text { time (days) }} \times 100$

Body composition was determined using 20 fish from an initial sample and eight fish from each cage at the end of the experiment, totaling 32 fish per treatment. Fish underwent 24-h fasting before weighed and slaughtered according to the protocol approved by the Animal Ethics Committee (CEUA) and the National Council for the Control of Animal Experimentation (CONCEA), (process no. 11394/15).

The fish were ground in a meat grinder and the samples freeze-dried before being used to determine dry matter (DM), crude protein (CP), fat by the acid hydrolysis method and ash. Gross energy (GE) was determined in a Parr bomb calorimeter pump, according to A.O.A.C. (2000) methods.

Body composition and performance data were used to calculate the protein productive value (PPV) and energy retention (ER), in addition to crude protein weight gain $\left(\mathrm{CP}_{\mathrm{WG}}\right)$ and ether extract for weight gain $\left(\mathrm{EE}_{\mathrm{WG}}\right)$, as follows:

$$
\begin{aligned}
& \operatorname{PPV}(\%)=\frac{[(\text { CPf } \times \text { Wf })-(\text { CPi } \times \text { Wi })]}{\text { crude protein intake }} \times 100 \\
& \operatorname{ER}(\%)=\frac{[(\text { GEf } \times \text { Wf })-(\text { GEi } \times \text { Wi })]}{\text { gross energy intake }} \times 100 \\
& (\mathrm{CPWG})_{\mathrm{WG}}(\%)=\frac{[(\mathrm{CPf} \times \mathrm{Wf})-(\mathrm{CPi} \times \mathrm{Wi})]}{(\text { final weight }- \text { initial weight })} \times 100 \\
& (\mathrm{EEWG})_{\mathrm{WG}}(\%)=\frac{[(\mathrm{EEf} \times \mathrm{Wf})-(\mathrm{EEi} \times \mathrm{Wi})]}{(\text { final weight }- \text { initial weight })} \times 100
\end{aligned}
$$


Table 1

Formulas and composition of test diets.

\begin{tabular}{|c|c|c|c|c|}
\hline \multirow[t]{2}{*}{ Ingredients $\left(\mathrm{g} \mathrm{Kg}^{-1}\right)$} & \multicolumn{4}{|l|}{ Diet } \\
\hline & $\mathrm{CHO}_{35} / \mathrm{LIP}_{9}$ & $\mathrm{CHO}_{39} / \mathrm{LIP}_{8}$ & $\mathrm{CHO}_{43} / \mathrm{LIP}_{7}$ & $\mathrm{CHO}_{47} / \mathrm{LIP}_{6}$ \\
\hline Poultry viscera meal $^{\mathrm{a}}$ & 80.00 & 80.00 & 80.00 & 80.00 \\
\hline Tilapia by-product meal $^{\mathrm{b}}$ & 35.50 & 35.50 & 35.50 & 35.50 \\
\hline Soybean mea ${ }^{c}$ & 278.00 & 257.00 & 213.00 & 58.50 \\
\hline Corn $^{\mathrm{d}}$ & 100.00 & 100.00 & 90.70 & 21.30 \\
\hline Wheat meal ${ }^{\mathrm{e}}$ & 100.00 & 94.00 & 92.00 & 20.00 \\
\hline Soybean oil ${ }^{\mathrm{f}}$ & 29.00 & 32.60 & 34.00 & 28.90 \\
\hline Broken rice ${ }^{g}$ & 40.50 & 90.00 & 83.00 & 70.00 \\
\hline Rice meal $^{\mathrm{h}}$ & 200.50 & 100.00 & 12.50 & 0.00 \\
\hline Cottonseed meal ${ }^{\mathrm{i}}$ & 75.00 & 65.00 & 10.00 & 0.00 \\
\hline Starch $^{\mathrm{j}}$ & 1.00 & 62.50 & 189.00 & 397.50 \\
\hline Corn gluten $^{\mathrm{k}}$ & 1.00 & 30.00 & 105.00 & 226.00 \\
\hline Vitamin $\mathrm{C}^{1}$ & 0.20 & 0.20 & 0.20 & 0.20 \\
\hline Dicalcium phosphate $^{\mathrm{m}}$ & 36.00 & 31.00 & 33.00 & 34.00 \\
\hline Limestone $^{\mathrm{n}}$ & 16.00 & 15.50 & 15.40 & 18.00 \\
\hline Antifungal $\left(\text { Phylax }^{\circledast}\right)^{\circ}$ & 1.50 & 1.50 & 1.50 & 1.50 \\
\hline Antioxidant $(\mathrm{BHT})^{\mathrm{p}}$ & 0.20 & 0.20 & 0.20 & 0.20 \\
\hline Vitamin-mineral supplement ${ }^{\mathrm{q}}$ & 5.00 & 5.00 & 5.00 & 5.00 \\
\hline Lysine $^{r}$ & 0.01 & 0.00 & 0.00 & 0.34 \\
\hline Methionine $^{s}$ & 0.05 & 0.00 & 0.00 & 0.00 \\
\hline Total & 1000.00 & 1000.00 & 1000.00 & 1000.00 \\
\hline \multicolumn{5}{|l|}{ Analyzed composition } \\
\hline Crude protein & 281.10 & 280.00 & 279.80 & 280.10 \\
\hline Digestible protein ${ }^{t}$ & 251.40 & 251.50 & 256.40 & 259.80 \\
\hline Ether extract & 90.50 & 80.00 & 69.90 & 60.10 \\
\hline Crude fiber & 60.50 & 48.00 & 30.70 & 16.00 \\
\hline Ash & 74.80 & 64.00 & 51.30 & 39.00 \\
\hline Nitrogen-free extract & 350.90 & 390.10 & 430.00 & 470.00 \\
\hline Gross energy $\left(\mathrm{Mj} \mathrm{Kg}^{-1}\right)$ & 17.39 & 17.42 & 17.51 & 17.74 \\
\hline Digestible energy $\left(\mathrm{Mj} \mathrm{Kg}^{-1}\right)^{\mathrm{t}}$ & 14.71 & 14.67 & 14.62 & 14.94 \\
\hline CHO:LIP ratio ${ }^{\mathrm{u}}$ & 3.89 & 4.87 & 6.14 & 7.83 \\
\hline Diets cost $(\mathrm{U} \$ \$ / 100 \mathrm{Kg})$ & 72.35 & 71.48 & 73.75 & 79.24 \\
\hline
\end{tabular}

CHO: carbohydrate; LIP: lipid.

${ }^{\text {a }}$ Nutreco Brasil Pitangueiras - SP, Protein = 635.1; Ether extract $=137.9$; Crude energy $\left(\mathrm{Mj} \mathrm{Kg}^{-1}\right)=20.24$.

b Nutreco Brasil Pitangueiras - SP, Protein = 541.4; Ether extract $=105.7$; Crude energy $\left(\mathrm{Mj} \mathrm{Kg}^{-1}\right)=17.06$.

c Agromix, Jaboticabal $-\mathrm{SP}$, Protein $=452.7$; Ether extract $=18.4$; Nitrogen-free extract $=292.6 \mathrm{Crude}$ energy $\left(\mathrm{Mj} \mathrm{Kg}{ }^{-1}\right)=17.45$.

${ }^{\mathrm{d}}$ FCAV/UNESP, Jaboticabal $-\mathrm{SP}$, Protein $=77.9$; Ether extract $=48.1$; Nitrogen-free extract $=726.3 \mathrm{Crude}$ energy $\left(\mathrm{Mj} \mathrm{Kg}^{-1}\right)=16.76$.

e Agromix, Jaboticabal $-\mathrm{SP}$, Protein $=157.0$; Ether extract $=40.4$; Nitrogen-free extract $=571.0 \mathrm{Crude}$ energy $\left(\mathrm{Mj} \mathrm{Kg}{ }^{-1}\right)=17.14$.

f Agromix, Jaboticabal $-\mathrm{SP}$, Ether extract $=1000.0$; Crude energy $\left(\mathrm{Mj} \mathrm{Kg}^{-1}\right)=39.06$.

g Agromix, Jaboticabal $-\mathrm{SP}$, Protein $=82.2$; Ether extract $=14.6$; Nitrogen-free extract $=761.9 \mathrm{Crude}^{\mathrm{energy}}\left(\mathrm{Mj} \mathrm{Kg}^{-1}\right)=15.93$.

h Agromix, Jaboticabal $-\mathrm{SP}$, Protein $=116.8$; Ether extract $=157.2$; Nitrogen-free extract $=421.2 \mathrm{Crude}$ energy $\left(\mathrm{Mj} \mathrm{Kg}^{-1}\right)=18.72$.

${ }^{\mathrm{i}}$ Agromix, Jaboticabal $-\mathrm{SP}$, Protein $=448.8$; Ether extract $=8.3$; Nitrogen-free extract $=282.4 \mathrm{Crude}$ energy $\left(\mathrm{Mj} . \mathrm{Kg}^{-1}\right)=17.78$.

j Agromix, Jaboticabal $-\mathrm{SP}$, Protein $=63.7$; Ether extract $=4.6$; Nitrogen-free extract $=830.2 \mathrm{Crude}$ energy $\left(\mathrm{Mj} \mathrm{Kg}^{-1}\right)=16.41$.

k Agromix, Jaboticabal $-\mathrm{SP}$, Protein $=638.4$; Ether extract $=47.3$; Nitrogen-free extract $=178.8 \mathrm{Crude}$ energy $\left(\mathrm{Mj} \mathrm{Kg}^{-1}\right)=21.93$.

1 Nutreco Brasil Pitangueiras - SP.

m Nutreco Brasil Pitangueiras - SP.

${ }^{n}$ Nutreco Brasil Pitangueiras - SP.

o Nutreco Brasil Pitangueiras - SP.

P Nutreco Brasil Pitangueiras - SP.

q Nutreco Brasil Pitangueiras - SP; Each 1\% contains: folic acid (1 mg); pantothenic acid (20 mg); antioxidant (125 mg); choline (150 mg); copper (10 mg); iron

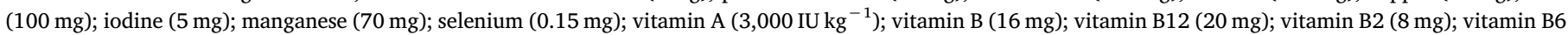
(3 mg); vitamin C (350 mg); vitamin D3 (3000 IU kg ${ }^{-1}$ ); vitamin E (200 IU kg ${ }^{-1}$ ); vitamin K (6 mg); zinc (150 mg); niacin (100 mg); biotin (0.10 mg).

$r$ Nutreco Brasil Pitangueiras - SP.

s Nutreco Brasil Pitangueiras - SP.

t Calculated based on Pezzato et al., (2002).

u The carbohydrate and lipid ratios were calculated as follows: CHO:LIP ration = Nitrogen-free extract/Ether extract.

where:

$\mathrm{CP}_{\mathrm{F}}, \mathrm{GE}_{\mathrm{F}}, \mathrm{EE}_{\mathrm{F}}$ : final crude protein, gross energy and ether extract in the carcass.

$\mathrm{CP}_{\mathrm{I}}, \mathrm{GE}_{\mathrm{I}}, \mathrm{EE}_{\mathrm{I}}$ : initial crude protein, gross energy and ether extract in the carcass.

$\mathrm{I}_{\mathrm{CP}}, \mathrm{I}_{\mathrm{CE}}$ : total protein and energy intake.

$\mathrm{W}_{\mathrm{i}}, \mathrm{W}_{\mathrm{F}}$ : initial and final body weight.

Four others fish per cage were individually weighed and dissected to obtain liver and intraperitoneal fat samples for body condition indices including the viscerosomatic fat index (VSFI), hepatosomatic index (HSI) and liver glycogen. After evisceration, the fat and liver were removed from the viscera, weighed, and used in the following equations:

$$
\begin{aligned}
& \text { HSI }(\%)=\frac{\text { liver weight }}{\text { fish weight }} \times 100 \\
& \operatorname{VSFI~}(\%)=\frac{\text { visceral fat weight }}{\text { fish weight }} \times 100
\end{aligned}
$$


Table 2


ratios (expressed as dry matter percentage) per 120 days.

\begin{tabular}{|c|c|c|c|c|c|c|c|c|}
\hline & $3.89\left(\mathrm{CHO}_{35} / \mathrm{LIP}_{9}\right)$ & $4.87\left(\mathrm{CHO}_{39} / \mathrm{LIP}_{8}\right)$ & $6.14\left(\mathrm{CHO}_{43} / \mathrm{LIP}_{7}\right)$ & $7.83\left(\mathrm{CHO}_{47} / \mathrm{LIP}_{6}\right)$ & CV (\%) & ANOVA $^{a}$ & Linear trend ${ }^{\mathrm{a}}$ & Quadratic trend ${ }^{\mathrm{a}}$ \\
\hline WG(\%) & $230.15 \pm 9.78 b$ & $248.47 \pm 4.18 \mathrm{a}$ & $252.01 \pm 11.87 \mathrm{a}$ & $247.60 \pm 0.88 \mathrm{a}$ & 3.26 & 0.0001 & 0.0018 & 0.0001 \\
\hline FI $(g)$ & $452.21 \pm 6.36 \mathrm{~b}$ & $464.82 \pm 6.37 b$ & $462.08 \pm 5.06 \mathrm{~b}$ & $422.53 \pm 5.64 \mathrm{a}$ & 1.31 & $1.41 \times 10^{-6}$ & $3.55 \times 10^{-6}$ & $6.38 \times 10^{-6}$ \\
\hline FCR & $1.27 \pm 0.01 \mathrm{c}$ & $1.18 \pm 0.01 \mathrm{~b}$ & $1.17 \pm 0.05 b$ & $1.10 \pm 0.03 \mathrm{a}$ & 2.61 & $6.29 \times 10^{-5}$ & $9.12 \times 10^{-6}$ & 0.3690 \\
\hline PER & $2.82 \pm 0.03 \mathrm{~b}$ & $3.01 \pm 0.04 \mathrm{a}$ & $3.05 \pm 0.11 \mathrm{a}$ & $3.24 \pm 0.07 \mathrm{a}$ & 2.59 & $5.98 \times 10^{-5}$ & $7.5 \times 10^{-6}$ & 0.5481 \\
\hline PPV(\%) & $43.15 \pm 2.86$ & $44.30 \pm 5.24$ & $43.33 \pm 3.18$ & $48.26 \pm 3.98$ & 8.76 & 0.2700 & 0.106 & 0.383 \\
\hline ER (\%) & $47.65 \pm 5.50 \mathrm{~b}$ & $55.13 \pm 1.57 \mathrm{ab}$ & $57.17 \pm 4.16 \mathrm{a}$ & $56.33 \pm 1.76 \mathrm{a}$ & 6.74 & 0.0114 & 0.0084 & 0.0236 \\
\hline $\mathrm{CP}_{\mathrm{WG}}(\%)$ & $17.17 \pm 1.32$ & $16.79 \pm 1.79$ & $15.75 \pm 1.54$ & $15.82 \pm 0.99$ & 8.79 & 0.4400 & 0.1550 & 0.5650 \\
\hline $\mathrm{EE}_{\mathrm{WG}}(\%)$ & $11.40 \pm 0.84 \mathrm{~b}$ & $11.96 \pm 0.79 \mathrm{ab}$ & $13.71 \pm 1.47 \mathrm{a}$ & $13.83 \pm 1.04 \mathrm{a}$ & 8.39 & 0.0148 & 0.0030 & 0.3060 \\
\hline GLYH(\%) & $6.05 \pm 1.11$ & $6.54 \pm 0.53$ & $5.73 \pm 0.37$ & $5.63 \pm 0.55$ & 11.48 & 0.1670 & 0.2413 & 0.7045 \\
\hline HSI (\%) & $1.71 \pm 0.15 b$ & $1.85 \pm 0.17 \mathrm{~b}$ & $2.43 \pm 0.25 \mathrm{a}$ & $2.61 \pm 0.27 \mathrm{a}$ & 9.95 & 0.0001 & $1.86 \times 10^{-5}$ & 0.3770 \\
\hline VSFI (\%) & $3.89 \pm 0.43 \mathrm{~b}$ & $3.77 \pm 0.43 b$ & $4.93 \pm 0.52 a$ & $5.12 \pm 0.09 \mathrm{a}$ & 9.10 & 0.0006 & 0.0001 & 0.7476 \\
\hline
\end{tabular}



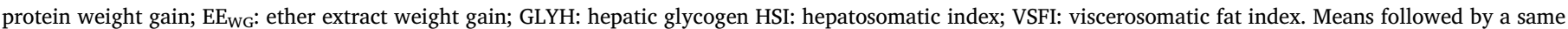
letter in a line do not differ statistically (Tukey's test, $\mathrm{P}>0.05$ ). CV: coefficient of variation.

${ }^{\text {a }}(\mathrm{Pr}>\mathrm{F})$ Significance probability associated with the F-statistic.

The livers collected were wrapped in aluminum foil and stored at $-80^{\circ} \mathrm{C}$. Liver glycogen levels were determined according to the method proposed by Perry et al., 1988.

\subsection{Statistical analysis}

Normality of data errors and homoscedasticity of variances were tested (Cramer Von-Mises and Brown Forsythe test, respectively) before data were subjected to analysis of variance. Data were also analyzed by the quadratic polynomial regression model, and when differences were non-significant, data means were compared by the Tukey test at 0.05 error probability. Statistical analyses were conducted using the 3.2.0 R Project for Statistical Computing (Copyright (C) 2015 The $R$ Foundation for Statistical Computing) (R Core Team, 2015).

\subsection{Economic evaluation}

Assessment of economic performance was based on the partial cost analysis described by Tung (1990) and Shang (1990). This procedure consists of analyzing the partial costs and incomes of a proposed business as a function of operational adjustments, considering that possible alterations over the production period analyzed do not require the application of a global budget to adjust a production protocol.

The cost variables related to the feed (mean feed intake $\mathrm{x}$ feed price per kilogram), labor (hours of feeding $\mathrm{x}$ hourly labor cost) and fish purchases (fish price $\mathrm{x}$ stocking density) were calculated first. To assess the economic impact of the diets, a market price survey was carried out to obtain ingredient prices from three feed manufacturing companies in the state of São Paulo. Calculations of business input considered $15 \mathrm{~min}$ per feeding time and one hour total per day, the amount of feed required for a production cycle, in days, and the unit labor cost of US\$ 2.05 an hour, based on the minimum monthly wage in São Paulo state (US\$ 345.37), plus $43 \%$ social contributions for 220 working hours a month. The incomes were calculated by multiplying the final biomass yield of each treatment $\left(4 \times 1 \mathrm{~m}^{3}\right)$ by the sales price per live fish kilogram, which was set at US\$1.53, the mean price for direct sale to fish processing plants. All amounts were quoted in $\mathrm{R} \$$ and converted into American dollars at the January 2018 conversion rate of $\mathrm{R} \$ 1.00=\mathrm{US} \$$ 0.3063

Based on feed, labor and fish purchase costs, in addition to income from sales to fish processing plants, the partial net income calculated corresponds to the gross income subtracted from feed, labor and fish purchase costs. The partial net income was calculated as follows:

Partial Net Income $=$ Gross Income - Partial Cost (feed, labor and fish $)$

\section{Results}

All the productive parameters of the Nile tilapia assessed showed significant differences as a function of the CHO:LIP ratios evaluated (Table 2) and the survival was $100 \%$ for all dietary treatments.

Mean percent WG was the lowest in the treatment with a CHO: LIP ratio of 3.89, reaching $230,15 \%$ (Table 2). The other CHO:LIP ratios did not have significant difference, having superior percent weight gain.

The increased CHO: LIP ratios in diets improved the mean SGR of the fish until 6.14 and a low in the highest ratio. The others ratio did not differ statistically. The best FCR mean (1.10) was produced by the diet with the highest $\mathrm{CHO}$ content (CHO:LIP ratio of 7.83), possibly because fish from this treatment exhibited lowest feed intake, with similar growth of $\mathrm{CHO}_{39} / \mathrm{LIP}_{7}$ and $\mathrm{CHO}_{43} / \mathrm{LIP}_{7}$ (Table 2). The high CHO level (47\% nitrogen-free extract) may have been excessive for Nile tilapia feed intake in net-cages.

In the present study, the lower CHO: LIP ratio in diet (3.89) promoted the lowest PER mean. Increasing CHO: LIP ratios, fish showed PER mean with higher utilization of dietary protein. (Table 2).

The $\mathrm{ER}$ and $\mathrm{EE}_{\mathrm{WG}}$ mean values were higher $(\mathrm{P}<0.05)$ in fish fed diets with a higher CHO:LIP ratio (6.14 and 7.83) (Table 2).

The hepatosomatic (HSI) and viscerosomatic fat (VSFI) indexes were different for the various treatments $(\mathrm{P}<0.05)$, with higher mean values for CHO:LIP ratios of 6.14 and 7.83 (Table 3). HSI is sensitive in detecting energy availability in fish. In the present study, an increase in HSI was likely caused by glycogen or LIP deposition, given the excess of diet digestible energy. Hepatic glycogen did not differ among the treatments (Table 2), but the CHO:LIP ratios of 6.14 and 7.83 increased HSI mainly due to the rise in liver fat.

The cost of $100 \mathrm{~kg}$ of feed calculated for the test diets described in Table 1, was US\$ 72.35 for $\mathrm{CHO}_{35} / \mathrm{LIP}_{9}$, US\$ 71.48 for $\mathrm{CHO}_{39} / \mathrm{LIP}_{8}$, US $\$ 73.75$ for $\mathrm{CHO}_{43} / \mathrm{LIP}_{7}$ and US\$ 79.24.42 for $\mathrm{CHO}_{47} / \mathrm{LIP}_{6}$. In addition, a fixed value of US\$ 0.2144 per feed kilogram was included in feed costs to cover expenses with processing and packing. The treatment with the lowest CHO:LIP ratio (3.89) had the lowest partially effective operational cost (US\$194.71) but exhibited the lowest weight gain in fish and the lowest net income, while the $\mathrm{CHO}_{39} / \mathrm{LIP}_{8}$ and $\mathrm{CHO}_{43} / \mathrm{LIP}_{7}$ treatments (CHO:LIP ratios of 4.87 and 6.14, respectively) yielded the highest partial net income (75.27 and 73.40, respectively) (Table 3).

The chemical parameters of water quality remained within the levels considered adequate for fish development (Sipaúba-Tavares, 2013). The ammonia concentration remained below the critical level of $1.0 \mathrm{mg} \mathrm{L}^{-1}$ (Boyd, 1982). The nitrate levels were within the range recommended by Boyd (1990), below $5000 \mu \mathrm{g} \mathrm{L}^{-1}$ and the acceptable maximum value of the nitrite concentration in a culture is $1.0 \mathrm{mg} \mathrm{L}^{-1}$. (Pádua, 1993, reported by Salvador et al., 2003). The study was performed from fall to 
Table 3

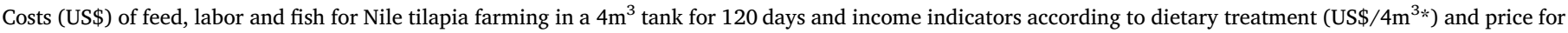
direct sales to fish processing plants, in January 2018.

\begin{tabular}{|c|c|c|c|c|c|c|c|c|c|c|c|c|}
\hline \multirow[t]{2}{*}{ Costs } & \multicolumn{3}{|c|}{$\mathrm{CHO}_{35} / \mathrm{LIP}_{9}$} & \multicolumn{3}{|c|}{$\mathrm{CHO}_{39} / \mathrm{LIP}_{8}$} & \multicolumn{3}{|c|}{$\mathrm{CHO}_{43} / \mathrm{LIP}_{7}$} & \multicolumn{3}{|c|}{$\mathrm{CHO}_{47} / \mathrm{LIP}_{6}$} \\
\hline & Amount & Unit cost & Total cost & Amount & Unit cost & Total cost & Amount & Unit cost & Total cost & Amount & Unit cost & Total cost \\
\hline \multicolumn{13}{|l|}{ Expenses } \\
\hline Feed (Kg) & 144.71 & 0.72 & 104.70 & 148.04 & 0.71 & 105.81 & 147.32 & 0.74 & 108.65 & 135.21 & 0.79 & 107.14 \\
\hline Labor (hours of feeding) & 15.60 & 2.24 & 35.02 & 15.60 & 2.24 & $\begin{array}{l}35 ; 02 \\
54.99\end{array}$ & 15.60 & 2.24 & 35.02 & 15.60 & 2.24 & 35.02 \\
\hline $\begin{array}{l}\text { Fish purchase } \\
\text { Income }\end{array}$ & 320.00 & 0.17 & 54.99 & 320.00 & 0.17 & 54.99 & 320.00 & 0.17 & 54.99 & 320.00 & 0.17 & 54.99 \\
\hline Mean fish price (US\$/kg) & & & 1.53 & & & 1.53 & & & 1.53 & & & 1.53 \\
\hline Yield $\left(\mathrm{kg} / 4 \mathrm{~m}^{3},{ }^{\mathrm{a}}\right)$ & & & 165.69 & & & 176.96 & & & 177.60 & & & 174.40 \\
\hline Partial effective operational cost (US\$. $4 \mathrm{~m}^{3}$ ) & & & 194.71 & & & 195.82 & & & 198.67 & & & 197.15 \\
\hline Gross income (US $\$ / 4 \mathrm{~m}^{3}$ ) & & & 253.82 & & & 271.09 & & & 272.07 & & & 267.17 \\
\hline Partial net income (US\$/4m ${ }^{3}$ ) & & & 59.12 & & & 75.27 & & & 73.40 & & & 70.02 \\
\hline
\end{tabular}

Partial Net Income $=$ Gross Income-Partial Cost (feed, labor and fish ).

a A junction between replicates was performed to better represent the partial economy analysis. The value of $4 \mathrm{~m} 3 \mathrm{represents}$ four net cage of $1 \mathrm{~m} 3$ each.

early winter, with temperature dropping to the limit of the fish acceptable but approaching the lower tolerable range for Nile tilapia and may affect fish feed intake and specific growth rate decline (Fig. 1).

\section{Discussion}

The diets were acceptable by tilapia independent of the variability in CHO/LIP ratios. This indicated that both carbohydrates and lipids were used within the levels for optimally growth.

Carbohydrates and lipids are important sources of non-protein energy for fish nutrition and are widely used in aquaculture (Boonanuntanasarn et al., 2018, Kamalam et al., 2017, Xie et al., 2017, García-Meilán et al., 2014; Wang et al., 2014, Gao et al., 2009, Erfanullah and Jafri, 1999). The carbohydrate and lipids have the function/are used to spare protein for growth or muscle deposition.

We observed an increase in percent WG when the CHO:LIP ratio increased. On the other hand, the SGR increased until 6.14 CHO/LIP ratio. In previous studies on Nile tilapia, acceptable CHO:LIP ratios have been reported to range from 2.06 to 4.95 (Ali and Al-Asgah, 2001), smaller value compared to our results. Erfanullah and Jafri (1999) observed higher WG and higher SGR for Catla catla and Labeo rohita in a CHO:LIP ratio of 8.93, but for Cirrhinus mrigal, the best performance was observed for fish fed diets with CHO:LIP ratio 3.38. In Catla catla, however, an increase in diet LIP above $4 \%$ decreased growth (Seenappa and Devaraj, 1995). In a study on Piaractus brachypomus, Vásquez-Torres et al. (2002) studied nine isoprotein diets (32\%), combining 20, 28 and 36\% CHO and 4, 8 and 12\% LIP, and found a significant growth decline when LIP levels increased from 8 to $12 \%$. Anderson et al. (1984) also observed that growth rates of Nile tilapia were improved with increasing carbohydrate levels in the diets from 0 to $40 \%$. These results indicate that the carbohydrate utilization varies among fish species and the $47 \%$ of carbohydrate was close to the limit that tilapia could use. It was possible to increase the levels of $4.87 \mathrm{CHO}$ : LIP ratio to 7.83 CHO:LIP ratio without compromising growth.

Corroborating with in this study Abimorad and Carneiro (2007) suggested the use of $46 \%$ nitrogen-free extrac in diets with $4 \%$ LIP, which can be increased to $50 \%$ CHO and $8 \%$ LIP without compromising growth in pacu (Piaractus mesopotamicus) diets. For herbivorous and omnivorous freshwater fish species Li et al., 2014, also suggested that the fish would utilize better dietary carbohydrate if there was a reduction in dietary lipid content.

The feed conversion ratio (FCR) observed in this study varied according to the CHO: LIP ratios, with the best feed conversion ratio being the ratio of 7.83. In Piaractus mesopotamicus, Abimorad and Carneiro (2007) found the best FCR (2.5) using diets with 50\% CHO and 8\% LIP. Vásquez-Torres and Arias-Castellanos (2013) found the best FCR (1.08) with $360 \mathrm{~g} \mathrm{~kg}^{-1}$ of $\mathrm{CHO}$ in the diet of Piaractus brachypomus $(7.8 \pm 0.49 \mathrm{~g})$ juveniles. In general, herbivorous or omnivorous fish have a greater ability to use dietary carbohydrates than carnivorous fish (Hidalgo et al., 1999), possibly because of higher amylase activity and receptor affinity for insulin (Banos et al., 1998). Warm water fish are generally more efficient in the use of dietary carbohydrates than cold water fish (Wilson, 1994). Tilapias are a warm-water, omnivorous fish species that can use levels of digestible carbohydrates as high as $40 \%$ in their diets (Wang et al., 2005).

This study, with practical diets, the best PER was found in fish fed diets with $390 \mathrm{~g} \mathrm{Kg}^{-1}$ carbohydrate. In a study on the performance of hybrid tambacu (Colossoma macropomum X Piaractus mesopotamicus), Carneiro et al. (1994) obtained the best PER with 45\% CHO combined with the lowest energy level (16.32 $\left.\mathrm{MJ} \mathrm{kg}^{-1}\right)$, showing high efficiency in the use of this nutrient as an energy source. Meurer et al. (2002) reported that the PER was reduced as the lipid level in the diet increased, which demonstrates that the effect of lipid in sparing protein from the diet to energy production (Lovell, 1989). Corroborating with our founding a maximum mean of PER with diets containing $360 \mathrm{~g} \mathrm{~kg}^{-1}$ of carbohydrates was found in the study by Vásquez-Torres and AriasCastellanos (2013), indicating that the higher levels of this nutrient contributed significantly to increase the efficiency of the use of proteins diets for Piaractus brachypomus. Tilapia fed low lipid high CHO/LIP ratio diets metabolized less protein to meet their energy needs than fish fed the diets with low CHO/LIP ratio in diets, resulting in higher dietary protein retention in tissues.

Even with increased CHO:LIP ratios there were no significant differences between the means of protein productive value and crude protein weigth gain $\left(\mathrm{CP}_{\mathrm{WG}}\right)$. What were expected in this study, because the diets were isoprotein. However, an increase in CHO:LIP ratio from 6.14 to 7.83 improved fish ER and VSFI. Even attributing the fact that they have the same metabolic function, both are energy sources, the diets with high CHO/LIP ratios stored more visceral fat. The liver is considered a preeminent organ of lipogenesis in fish (Segner and Böhm, 1994), such that a portion of the absorbed carbohydrates, which is not used for energy, is converted and stored in the liver as lipid.

To maximize fish growth there must be a balance between carbohydrates and lipids and therefore, carbohydrates should be provided as cheaper sources of energy and lipid to supply fatty acids requirements (Ng and Romano, 2013). 
Considering the partial economic analysis, the diets that provided the highest productive performance brought better results. The diet containing CHO:LIP ratio of 7.83 obtained the best economic performance.

Considering the experimental conditions in a pre-winter season, the diet containing a CHO:LIP ratio of 7.83 (43\% CHO and 7\% LIP) best met the energy demands of Nile tilapia, resulting in the best productive performance, nutrient use efficiency, physiological index values and the most profitable with a partial net income of US\$ 72.19.

\section{Acknowledgments}

We thank the financial support from CNPq (no: 30.4828/2015-7) and Capes for the scholarships, and Aquaculture Center of UNESP.

\section{References}

Abimorad, E.G., Carneiro, D.J., 2007. Digestibility and performance of pacu (Piaractus mesopotamicus) juveniles - fed diets containing different protein, lipid and carbohydrate levels. Aquac. Nutr. 13, 1-9. https://doi.org/10.1111/j.1365-2095.2007. 00438.x

Ali, A., Al-Asgah, N.A., 2001. Effect of feeding differente carbohydrate to lipid retions on the growth performance and body composition of Nile Tilapia (Oreochromis niloticus) fingerlings. Anim. Res. 50, 91-100. https://doi.org/10.1051/animres:2001119.

Anderson, J., Jackson, A.J., Matty, A.J., Capper, B.S., 1984. Effects of dietary carbohydrate and fibre on the tilapia Oreochromis niloticus (Linn.). Aquaculture 37, 303-314.

AOAC - ASSOCIATION OF OFFICIAL ANALYTICAL CHEMISTS, 2000. Official methods of analysis of the Association of Agriculture Chemists, 17th ed. AOAC, Arlington, pp. 2.

Banos, N., Baro, J., Castejon, C., Navarro, I., Gutierrez, J., 1998. Influence of highcarbohydrate enriched diets on plasma insulin levels and insulin and IGF-I receptors in trout. Regul. Pept. 77, 55-62.

Boonanuntanasarn, S., Kumkhong, S., Yoohat, K., Plagnes-Juan, E., Burel, C., Marandel, L., Panserat, S., 2018. Molecular responses of Nile tilapia (Oreochromis niloticus) to different levels of dietary carbohydrates. Aquaculture 482, 117-123.

Boyd, C.E., 1982. Water Quality Management for Pond Fish Culture. Elsevier Scientific Publishing Company, Amsterdam, Netherlands.

Boyd, C.E., 1990. Water Quality in Warm Water Fish Ponds. Alabama Agricultural Experiment Station, Auburn University, Auburn, Alabama, USA.

Carneiro, D.J., Fragnito, P.S., Malheiros, E.B., 1994. Influence of carbohydrate and energy level on growth and body composition of tambacu, a hybrid of tambaqui (Colossoma macropomum ()) and pacu (Piaractus mesopotamicus $\sigma^{7}$ ). Aquaculture 124, 129-130. https://doi.org/10.1016/0044-8486(94)90372-7.

Chou, B.-S., Shiau, S.-Y., 1996. Optimal dietary lipid level for growth of juvenile hybrid tilapia, Oreochromis niloticus 9 Oreochromis aureus. Aquaculture 143, 185-195.

El-Sayed, A.M., Garling, D.L., 1998. Carbohydrate-to-lipid ratio in diets for Tilapia zilli fingerlings. Aquaculture 73, 157-163.

Erfanullah, Jafri, A.K., 1999. Growth, feed conversion, body composition and nutrient retention efficiencies in fingerling catfish, Heteropneustes fossilis (Bloch), fed different sources of dietary carbohydrate. Aquac. Res. 30, 43-49. https://doi.org/10.1046/j 1365-2109.1999.00298.x.

FAO, 2017. Fisheries and Aquaculture Technical Paper 541. FAO, Rome, pp. 63 (copyright@fao.org).

Gao, W., Liu, Y.J., Tian, L.X., Mai, K.S., Liang, G.Y., Yang, H.J., Huai, M.Y., Luo, W.J., 2009. Protein-sparing capability of dietary lipid in herbivorous and omnivorous freshwater finfish: a comparative case study on grass carp (Ctenopharyngodon idella) and tilapia (Oreochromis niloticus $\times 0$, aureus). Aquaculture 17 (1), 2-12.

Golterman, H.L., Clymo, R.S., Ohnstadt, M.A.M., 1978. Methods for Physical and Chemical Analysis of Freshwaters -1BP Handbook No 8, 2nd edition. 213 S Blackwell Scientific Publications, Oxford, Edinburgh, London, Melbourne. https://doi.org/10. 1002/iroh.19800650113. zahlr. Abb. u. Tab., Preis £ 6.00. Int. Revue ges. Hydrobiol. Hydrogr., 65: 169.

He, A.Y., Ning, L.J., Chen, L.Q., Chen, Y.L., Xing, Q., Li, J.M., Qiao, F., Li, D.L., Zhang, M.L., Du, Z.Y., 2015. Systemic adaptation of lipid metabolism in response to low- and high-fat diet in Nile tilapia (Oreochromis niloticus). Physiol. Rep. 3 (8), e12485.

Hemre, G.I., Deng, D.F., 2015. Carbohydrates - chapter 4. In: Lee, C.S., Lim, C., Gatlim, D.M., Webster, C.D. (Eds.), Dietary Nutrients Additives \& Fish Health. Dietary Nutrients, Additives, and Fish Health. Wiley Blackwell, pp. 95-110.

Hidalgo, M.C., Urea, E., Sanz, A., 1999. Comparative study of digestive enzymes in fish with different nutritional habits. Proteolytic and amylase activities. Aquaculture 170 (3), 267-283.

Hisano, H., Portz, L., 2007. Redução de custos de rações para tilápia: a importância da proteína. Bahia Agricola 8, 42-45.

IBGE - Instituto Brasileiro de Geografia e Estatística, 2016. Produção da pecuária municipal/IBGE. - V.1 (1973-). IBGE, Rio de Janeiro 1974-v. Annual. https://biblioteca ibge.gov.br/visualizacao/periodicos/84/ppm_2016_v44_br.pdf (Accessed 27 September 2017)

Kamalam, B.S., Patiyal, R.S., Rajesh, M., Mir, J.I., Singh, A.K., 2017. Prolonged transport of rainbow trout fingerlings in plastic bags: optimization of hauling conditions based on survival and water chemistry. Aquaculture 480, 103-107. https://doi.org/10. 1016/j.aquaculture.2017.08.012.

Koroleff, F., 1976. Determination of nutrients. In: Granshoff, K. (Ed.), Methods of Seawater Analysis. Verlag Chemie, Weinhein, pp. 117-181.

Leenhouwers, J.I., Ortega, R.C., Verreth, J.A.J., Schrama, J.W., 2007. Di-gesta characteristics in relation to nutrient digestibility and mineral absorption in Nile tilapia (Oreochromis niloticus L.) fed cereal grains of increasing viscosity. Aquaculture 273, $556-565$.

Li, X., Zhu, X., Han, D., Yang, Y., Jin, J., Xie, S., 2014. Carbohydrate utilization by herbivorous and omnivorous freshwater fish species: a comparative study on gibel carp (Carassius auratus gibelio. var CAS III) and grass carp (Ctenopharyngodon idellus). Aquaculture 47 (1), 128-139.

Li, A., Yuan, X., Liang, X.-F., Liu, L., Li, J., Li, B., Fang, J., Li, J., He, S., Xue, M., Wang, J., Tao, Y.-X., 2016. Adaptations of lipid metabolism and food intake in response to low and high fat diets in juvenile grass carp (Ctenopharyngodon idellus). Aquaculture 457, 43-49.

Lim, C., Webster, C.D., 2001. Nutritional and Fish Health. The Howorth Press, Inc, Binghamton, New York.

Lovell, R.T., 1989. Nutrition and Feeding of Fish. Van Nostrand Reinhold (260p).

Mackereth, F.J.H., Heron, J.E., Talling, J.F., 1978. Water analyses: Some revised methods for limnologists. Scient. Public 121. https://doi.org/10.1002/iroh.19790640404.

Meurer, F., Hayashi, C., Boscolo, W.R., Soares, C.M., 2002. Lipídios na alimentação de alevinos revertidos de tilápia do Nilo (Oreochromis niloticus, L.). Rev. Bras. Zootec. 33, 566-573. https://doi.org/10.1590/S1516-35982002000300005.

Moro, G.V., Silva, T.S.C., Cyrino, J.E.P., 2015. Feed processing affected the digestibility of carbohydrate sources for dourado Salminus brasiliensis. Aquac. Nutr. 23, 40-45.

Ng, W.K., Romano, N., 2013. A review of the nutrition and feeding management of farmed tilapia throughout the culture cycle. Rev. Aquac. 5, 220-254.

Perry, S.F., Walsh, P.L., Mommsen, T.P., Moon, T.W., 1988. Metabolic consequences of hypercapnia in the rainbow trout, Salmo gairdneri:/J-adrenergic effects. Gen. comp. Endocr. 69, 439-447. https://www.researchgate.net/publication/20322508 Metabolic_consequences_of_hypercapnia_in_the_rainbow_trout_Salmo_gairdneri_bAdrenergic effects.

Pezzato, L.E., Miranada, E., Barros, C., Pinto, M.M., Furuya, L.G.Q., Pezatto, W.M., 2002. Digestibilidade aparente de ingredientes pela tilápia do Nilo (Oreochromis niloticus). Rev. Bras. Zool. 31, 1595-1604. https://doi.org/10.1590/S151635982002000700001

R Core Team, 2015. R: A language and environment for statistical computing. In: R Foundation for Statistical Computing. R Core Team, Vienna, Austria URL. https:// www.R-project.org/.

Salvador, R., Muller, E.E., Leonhardt, J.H., Giordano-Pretto, L.G., Dias, J.A., Freitas, J.C., Moreno, A.M., 2003. Isolamento de Streptococcus spp de tilápias do Nilo (Oreochromis niloticus) e qualidade da água de tanques rede na Região Norte do Estado do Paraná, Brasil. Ciên. Agrárias 24, 35-42. https://doi.org/10.5433/1679-0359. 2003v24n1p35.

Seenappa, D., Devaraj, K.V., 1995. Effect of different levels of protein, fat and carbohydrate on growth, feed utilization and body carcass composition of fingerlings of Catla catla (Ham.). Aquaculture 129, 243-249. https://doi.org/10.1016/0044-8486(94) 00273-Q.

Segner, H., Böhm, R., 1994. Enzymes of lipogenesis. In: Biochemistry and Molecular Biology of Fishes, Analytical Techniques. 3. pp. 313-325.

Shang, Y.C., 1990. Partial budget analysis. In: Aquaculture Economic Analysis: A Introduction. 2. The World Aquaculture Society, Honolulu, pp. 47-49.

Sipaúba-Tavares, L.H., 2013. Uso racional da água em aquicultura. FUNEP/UNESP, São Paulo, Brazil.

Tran-Duy, A., Schrama, J.W., van Dam, A.A., Verreth, J.A.J., 2008. Effects of oxygen concentration and body weight on maximum feed intake, growth and hematological parameters of Nile tilapia, Oreochromis niloticus. Aquaculture 275, 152-162.

Tung, N.H., 1990. Orçamento parcial: caracterização. In: Tung, N.H. (Ed.), Planejamento e controle financeiro das empresas agropecuárias. Edições Universidade Empresa, São Paulo, pp. 271-278.

Vásquez-Torres, W., Arias-Castellanos, 2013. Effect of dietary carbohydrates and lipids on growth in cachama (Piaractus brachypomus). Aquac. Res. 44 (11), 1768-1776.

Vásquez-Torres, W., Pereira Filho, M., Arias-Castellanos, J.A., 2002. Estudos para Composição de uma Dieta Referência Semipurificada para Avaliação de Exigências Nutricionais em Juvenis de Pirapitinga, Piaractus brachypomus (Cuvier, 1818). R. Bras. Zootec. 31, 283-292. https://doi.org/10.1590/S1516-35982002000200001.

Veras, G.C., 2013. Fotoperíodo sobre parâmetros fisiológicos relacionados ao estresse em alevinos de tilápia do Nilo. Arquivo Bras. Med. Veterin. Zootec. Belo Horizonte 65, 1434-1440. https://doi.org/10.1590/S0102-09352013000500023.

Wang, Y., Liu, Y.J., Tian, L.X., Du, Z.Y., Wang, J.T., Wang, S., Xiao, W.P., 2005. Effects of dietary carbohydrate level on growth and body composition of juvenile tilapia, Oreochromis niloticus $\times$ O. aureus. Aquac. Res. 36 (14), 1408-1413.

Wang, L.N., Liu, W.B., Zhang, C.N., Li, X.F., Xu, W.N., Cai, D.S., Tian, H.Y., 2014. Effects of dietary non-protein energy sources on growth, physiology and biochemistry of yellow catfish (Pelteobagrus fulvidraco) J. Nanjing Agric. Univ. 37, 108-114.

Wilson, R.P., 1994. Utilization of dietary carbohydrate by fish. Aquaculture 124, 67-80

Zhou, C., Ge, X., Liu, B., Xie, J., Chen, R., Ren, M., 2015. Effect of high dietary carbohydrate on the growth performance, blood chemistry, hepatic enzyme activities and growth hormone gene expression of Wuchang Bream (Megalobrama amblycephala) at two temperatures. Asian Australas. J. Anim. Sci. 28 (2), 207-214. 